This in its turn explains the smaller storage in larger numbers of pregnancies.

As the skin in particular has been the place where arsenic was stored, it has been studied in more detail, whereby it has been seen that sexual functions and sexual hormones bring about an obvious check to the spreading possibilities which the skin otherwise shows, and also that they give rise to an increase in the thickness of the corium and a distinct increase of non-ether-soluble dry substances reckoned per unit skin surface. These results all seem to explain the increase of arsenic storage in the skin of both $m$ and $u$ animals dosed with Antex, Leo, or castrates which have been given Ovex, Leo (= costrone), and testosterone respectively.

The expenses of this investigation were defrayed by grants from Stiftelsen Thé: èse och Johan Anderssons Minne, The Caroline Institute, Stockholm, and from the Regnells fund of the University of Uppsala.

+Agduhr, Erik, Verhandl. Anatom. Gesellsch. Erg. z. Anat. Anzeig., "7, 63 (1931).

'Agduhr, Erik, Upsala läkarefören. förhandl., N.F. 38, 1 (1932).

${ }^{3}$ Agduhr, Erik, (a) Upsala läkareförenings förh., N.F. 38, IV (1982) ; ibid., 39, 307 (1934); ibid., 40.183 (1935); ibid. 42, 463 (1937) ibid. 43, 1 (1937); ibid., 47, 1 (1941); (b) Verhandl. Anat. Gesellsch. Erg. z. Anat. Anz., 72, 63 (1931); (c) Z. mikrosk. anatom. Forschung, 36, 576 (1934); ibid., 45, 3; S. 467 (1939); ibid. 49, $589(1941)$; (d) Z. Vitaminforsch., 4, 66 (19.35) : ibid., 6 27 (1936); (e) Skandinavisch. Arch. f. Physiol., 2 (1937); 5 th Northern Congress of Phvsiology, Uppsala (1937); ibid., 7,4 ibid., 77, 5 (1937); sbid., 78, 6 (1938) (f) Hygiea, 100, 2 (1938) (g) Meddelande fr. Sällskap. veterinärmedicinsk Forskning, 2 (1940); Skand. vet. tidskr. (1941); (h) Archiv. internation. Phar macodyn. et Thérap., 59, 269 (1938); (i) Acta Medica Scandinavica, 99, 387 (1939); ( j) Barron, D. H., Archiv. internation. Pharmacod. et Thérap., 58, 351 (1938).

4 Agduhr, Erik, Z. mikrosk. anatom. Forschung, 49, 603 (1941).

s $\frac{\boldsymbol{M}}{\Gamma \theta}=$ Mean for sixteen animals.

'Agduhr, Erik, Upsala Läkareför. förhandl., N.F., 47, 1 (1941)

- Agduhr, Erik, ibid., 38, IV (1932).

Agduhr, Erik, ibid., 47, 1 (1941).

\section{PERMIAN FOSSILS FROM THE EASTERN HIMALAYA*}

$\mathrm{I}^{\mathrm{N}}$ 1849, having traversed the igneous and metamorphic rocks of the Sikkim Himalaya, Joseph Hooker discovered a limestone containing fragmentary organic remains. The fossils were thought to be nummulites, but afterwards they were shown to be crinoid ossicles of uncertain age. Fifty years later, E. J. Garwood found that the high range bordering Sikkim to the west of Hooker's locality was formed of thick, altered limestones containing crinoid re. mains, and he considered that these limestones, probably Silurian or Carboniferous in age, were the westward extension of Hooker's limestone. On the other hand, Henry Hayden, in 1907, mapped the rocks east and north of Hooker's locality and proved a sequence from Jurassic to Eocene ; he suggested that Hooker's limestone might be the equivalent of one of the Jurassic limestones found by him in southern Tibet.

The actual locality of Hooker's find was not revisited until after the 1933 Mount Everest Expedition. On this occasion small collections of fossils were made which form the subject of this paper, one from Hooker's locality, another from a horizon in the Lachi Hills near by, and a third from erratic material derived from the Mount Everest Limestone Series, *"Upper Palaeozoic Faunas of North Sikkim." By Helen M.
Muir-Wood and Kenneth P. Oakley. Palcontologica Indica, New Series, 31, Mem. No. 1. Pp. $91+4$ plates (1941). which includes the limestones of North Sikkim first described by Garwood. The valuable results obtained from this scanty and badly preserved material, which was collected by the present reviewer, are a tribute to the skilful way in which the modern palæontologist works, extracting much of value from very little.

In the Lachi Hills overlooking Hooker's locality, an outcrop of the highly characteristic Mount Everest Limestone, which forms the summit of Mount Everest, was found to be overlain by quartzites, shales and pebbly sandstones which were named the Lachi Series. Brachiopods from a horizon in the Lachi Series are shown by Dr. Muir-Wood to include Marginifera himalayensis, Spiriferella rajah and Neospirifer moosakhailensis, and a valuable discussion of the affinities and distribution of these and some other species is provided. On the basis of the brachiopod fauna, Dr. Muir.Wood shows that this fossiliferous horizon in the Lachi Series is equivalent to the Productus Shales of Spiti and the Zewan Beds of Kashmir ; she also shows that it is probably of the same age as the upper Productus Limestone of the Salt Range, although of a somewhat different facies. The relation of these Tethyan deposits to the Permian succession in Russia is considered and the conclusion reached that this horizon of the Lachi Series is Upper Permian. Molusca and Bryozoa, described by Dr. Oakley, support the hypothesis of the Upper Permian age of the beds.

The few organic remains from Hooker's limestone, only a single block of which could be brought back owing to transport difficulties, indicate a probable Permian or Triassic age. The fossils include a new species of Solenopora, the first species to be described from the Permian of a genus which ranges from the Lower. Palæozoic to the Jurassic. To his description Dr. Oakley appends a valuable discussion on the nature of the Solenoporaceæ, of which the algal affinities, although usually accepted, have been questioned in recent years by several authors. Dr. Oakley definitely rules out the Hydrozoa, and on the whole favours the algal view.

The thousand feet or so of the Lachi Series lying below the Upper Permian horizon consists first of pebble beds and then of shales and quartzites. Below these lies the Mount Everest Limestone Series, an important rock group of the Eastern Himalaya, the age of which has not yet been directly established. A few fossils, including immature rugose corals, indeterminate brachiopods and a new species of Straparollus collected from shales below the pebble beds are described by the authors, but they provide no precise estimate of age. Nor can the fragmentary fossils from the Mount Everest Limestone itself give any satisfactory evidence for the age of that horizon. However, the authors attempt to estimate, by means of lithological comparisons, the age of these pebble beds, which include horizons in which pebbles several inches in diameter occur in a matrix of silt grade. This unusual lithology led J. B. Auden to liken these rocks to the Blaini tillites. If this correlation be accepted, then, as Dr. Muir-Wood shows, the pebble beds would be Upper Carboniferous in age and the Lower Permian would be missing on Lachi. As a corollary the age of the Mount Everest Limestone Series would be Lower Carboniferous or even earlier.

It is considered that too much assurance has been placed in the tentative lithological correlation of the pebble beds; the authors even go so far as to state that the horizon is a glacial boulder bed ( $p .59)$, which is certainly an overstatement, so far as present 
evidence goes. It would seem to the reviewer quite as probable that there is no non-sequence on Lachi, that the pebble beds are Lower Permian in age, and that the Mount Everest Limestone Series is somewhat younger than is indicated on the assumption that the pebble beds are equivalent to the Blaini tillites. Providing, however, that arguments based on the possible glacial character of the Lachi pebble beds are regarded as no more than tentative, then the authors have done a service by working out the full implications of such a hypothesis.

These less secure deductions do not in any way obscure the main conclusion of the authors, that an Upper Permian horizon occurs north of the Himalaya in Sikkim. This provides a valuable terminus ad quem for dating the Mount Everest Limestone Series, a highly characteristic lithological unit, which should orie day be a most valuable guide in unravelling the structure of the Eastern Himalaya.

L. R. WAGER.

\section{A PROPOSED REFORMED MONETARY SYSTEM}

$\mathrm{A}^{\mathrm{N}}$

$\mathbf{N}$ interesting anonymous pamphlet designed to propose a reformed monetary system consistent with the requirements of post-war trade and economic intercourse between nations has recently been published*.

The author begins by saying that it will be indispensable after the War for nations which must have large exports in order to avoid the dislocation of their intermal economies to find outlets for these exports, even if the recipients are not in a position, at any rate for the time being, to repay on a commercial basis with exports of their own. He concludes that it will be necessary to maintain control over the foreign exchanges for a period after the War, and for exports to be made on a basis which will give the exporters the alternative of receiving payment in goods or not being paid at all, as it would be clearly foolish to begin again the practice of piling up unpayable debts.

Then the author sets out proposals for the structure for a permanent post-war system of international trade. This he proposes to anchor to two forms of stabilization-stabilization of the internal price level in each country, measured in terms of the average general level of prices, and stabilization on a permanent fixed basis of the rates of exchange of the moneys of different countries. Having done this, he proposes to conduct all foreign trade by what amounts to an international cloaring system, bilateral in the main but with provision for multilateral arrangements, and he suggests that all adverse balances not cleared by payment in goods to the creditor country within a period of seven years should be merely cancelled. Nations would then have no incentive to seek to export more than they are prepared to import, and would be in 8 position to adjust their economies to either a high or a low level of foreign trade actively.

It is clearly impossible to offer any effective criticism of these problems in a brief note. All that can be said is that the pamphlet sets forth cogently

- A Twentieth Century Economic System. Pp. 60. (London: Iconomic Reform Club, 1941.) $6 d$. the shortcomings of the existing financial system, but slides much too easily over the difficulties inherent in either price stabilization or permanent exchange stability - much more over the difficulties involved in a combination of these two systems.

G. D. H. Cole.

\section{AIR-RAID DAMAGE AND ELECTRICITY SUPPLY}

$\mathrm{R}$ ECENT articles in the Electrical Review disclose the steps which have been taken to overcome air-raid damage to the properties of electricity supply undertakings, and the measures taken to restore supply. Without giving away vital information to the enemy, it may be said that, of the very large number of bombs dropped during a period of twelve months, some have inevitably fallen on or near power stations. Thanks to the design of the modern power station and the special precautions taken against blast and fire, the actual damage has generally been superficial. One of the newest stations in Great Britain, for example, which received a direct hit on the boiler house roof, sustained no damage that a few bricklayers and concreters could not make good in a few weeks, and the plant itself was unscathed.

An interesting and noteworthy experience arising from raids is that in the older types of buildings, damage appears to be limited to wood-supported roofs, and it is recommended that roofing be as thin as possible. The incendiary bomb will then pierce the roof and burn harmlessly on the concrete floor below, glancing off machinery, which should be suitably protected to ensure this. In this connexion "Durasteel", which has been used for the protection of switchboards and other vital apparatus and machinery, has fully justified the claims made for it. Several instances have been observed in which valuable plant has been saved by its use, the only noticeable damage to itself being discoloration.

Though incendiary fires in substations are uncommon it is desirable, in the interests of the safety of A.F.S. personnel, that the latter should notify the undertaking if fires occur adjacent to and threatening any of its property, as the A.F.S. is not normally provided with the necessary foam apparatus for dealing with burning transformer oil and outbreaks among live gear.

The greatest amount of damage experienced has been, not unexpectedly, that caused by bombs to underground cables. Experience has shown, however, that paper insulated, lead-sheathed and armoured cable stands up to very severe damage, irrespective of voltage, one instance occurring where only the electric cables supported a damaged bridge.

Numerous instances have occurred where cables, depressed and twisted many feet below the laid level, have not failed. Examination has revealed that sometimes, though not always, the stretching of directly laid cables has been confined to the length in the crater, and has not extended to any appreciable length on either side, slack in adjacent manholes having frequently been sufficient to prevent damage to joints. Cables laid in ducts have been pulled along the duct towards the crater, joint wipes being torn away from the lead sheath, often two or three man. holes away. This pulling sometimes extended for 